\title{
Formation of ammonia bisulfate in coal-fired power plant equipped with SCR reactors and the effect of reduced load operation
}

\author{
Maciej Żyrkowski ${ }^{1,2,{ }^{*}}$, M onika M otak ${ }^{1}$ \\ ${ }^{1}$ AGH Akademia Górniczo - H utnicza, al. M ickiewicza 30, 30-059 Kraków, mzyrkow@ agh.edu.pl, Poland \\ 2 PGE Energia Ciepła S.A., ul. Złota 59, 00-120 W arszawa, Poland
}

\begin{abstract}
Coal fired power plant are still responsible for vast amount of electricity and heat production in Poland in 2019. Increasing number of units is equipped with SCR reactors in order to mitigate N Ox emission. Older units have been designed to work in a base load operation, however increasing number of intermittent energy sources on the market, forces power plant owners to operate such units in reduced load for significant number of hours in a year. M ost of parameters in coal-fired boiler would change in reduced load operation, particularly flue gas parameters. That would affect the formation of ammonia bisulfate $\left(\mathrm{NH}_{4} \mathrm{HSO}_{4}\right)$ as well as operation of SCR reactors in the boiler. The $\mathrm{NH}_{4} \mathrm{HSO}_{4}$ formation is highly undesired as it can plug the catalyst or heating surfaces in the boiler. To investigate this phenomenon, the $\mathrm{NH}_{4} \mathrm{HSO}_{4}$ formation was comprehensively studied. M oreover, reduced load operation of boiler in a medium size CHP plant was simulated, using computer modelling tools. Obtained parameters were used to analyse, how different flue gas parameters affect $\mathrm{NH}_{4} \mathrm{HSO}_{4}$ formation and what consequences does it have for boiler operation. In particular, effect related with operation of SCR reactors equipped with $\mathrm{V}_{2} \mathrm{O}_{5}-\mathrm{WO}_{3} / \mathrm{TiO}_{2}$ catalyst was deeply studied.
\end{abstract}

\section{Introduction}

A mmonia bisulfates formation is one of the major problems related to DeNOx installations, such as SCR (Selective Catalytic Reduction) or SNCR (Selective NonCatalytic Reduction), in solid fuels power plants. A mmonia $\left(\mathrm{NH}_{3}\right)$ that can escapes from these installations reacts with sulfur trioxide, forming compounds such as ammonium bisulfates $\mathrm{NH}_{4} \mathrm{HSO}_{4}$ and ammonium sulfates $\left(\mathrm{NH}_{4}\right)_{2} \mathrm{SO}_{4}$. The problem is related with the first one in particular - salt which at a temperature below its condensation point. forms sticky substance that covers porous structure of the SCR catalysts, as well as it can contaminate surfaces of the rotary air heater and the electrostatic precipitator [1] [2] [3] [4]. Because it condensates at a certain temperature, region that can be affected by plugging depends on the boiler load. The $\mathrm{NH}_{4} \mathrm{HSO}_{4}$ also passes in solid form to the fly ash, which results in increased ammonia content in the combustion by products.

\section{SO3 formation}

The $\mathrm{SO}_{3}$ in flue gas exists because of $\mathrm{SO}_{2}$ to $\mathrm{SO}_{3}$ conversion. Due to the fact that $\mathrm{SO}_{3}$ concentration is crucial for ammonia bisulfate formation, it is vital to discuss this mechanism in details. Sulfur in the combustion chamber is delivered together with the fuel. M odern solid fuels boilers use a division of the combustion process into a reduction zone (with oxygen deficiency) and a postcombustion zone (with excess oxygen). During combustion, sulfur contained in coal is oxidized according to the following reaction:

$\mathrm{S}+\mathrm{O}_{2}->\mathrm{SO}_{2}$

The largest amount of $\mathrm{SO}_{2}$ is formed in the first stage of combustion. Then, some part of $\mathrm{SO}_{2}$ is converted to $\mathrm{SO}_{3}$. The main parameters that support this process is temperature, the residence time of the particle, oxygen concentration, as well as the composition and size of the mineral fraction in fuel. The effect of temperature on the degree of conversion begins to be visible above $700^{\circ} \mathrm{C}$. However, the influence of temperature on the conversion process is small compared with catalytic influence, discussed in below [5]. Overall conversion in combustion zone is up to $2 \%$ [6].

A bove the area of the boiler where the combustion process has been completed, sulfur is mainly present in the form of $\mathrm{SO}_{2}$. The $\mathrm{SO}_{3}$ concentration depends on the sulfur content in fuel. Also, elements such as iron, nickel, wolfram, titanium and vanadium show catalytic properties for the conversion of $\mathrm{SO}_{2}$ to $\mathrm{SO}_{3}$. Thus, along with the increase of these elements in the fuel, the potential $\mathrm{SO}_{3}$ emission will also increase. On the other hand, the presence of alkaline elements may prevent this process by binding both $\mathrm{SO}_{2}$ and $\mathrm{SO}_{3}$ in the form of sulfates (e.g. $\mathrm{K}_{2} \mathrm{SO}_{4}, \mathrm{Na}_{2} \mathrm{SO}_{4}$ ) at temperature below $1000^{\circ} \mathrm{C}$. The highest intensity of catalytic reactions is recorded at a temperature of about $700{ }^{\circ} \mathrm{C}$ and their impact on the overall level of $\mathrm{SO}_{2}$ to $\mathrm{SO}_{3}$ conversion is much greater than other factors. Table 1 
shows the influence of temperature and the abovementioned catalysts on the $\mathrm{SO}_{2}$ conversion process. It can be seen, that at temperature of $700^{\circ} \mathrm{C}$ as much as $95 \%$ of the total conversion occurs due to the action of catalysts [7].

Table 1. Effect of temperature and catalysis on $\mathrm{SO}_{2}$ to $\mathrm{SO}_{3}$ conversion rate, based on [7]

\begin{tabular}{|l|l|l|l|}
\hline \multirow{2}{*}{ Temperature } & \multicolumn{2}{|l|}{ Conversion rate [\%] } & $\begin{array}{l}\text { Catalytic } \\
\text { effect on } \\
\text { conversion } \\
\text { [\%] }\end{array}$ \\
\cline { 2 - 4 } & $\begin{array}{l}\text { Temp. } \\
\text { effect }\end{array}$ & $\begin{array}{l}\text { Total } \\
\text { conversion }\end{array}$ \\
\hline $400^{\circ} \mathrm{C}$ & 0.041 & 0.042 & 1 \\
\hline $500^{\circ} \mathrm{C}$ & 0.062 & 0.077 & 19 \\
\hline $700^{\circ} \mathrm{C}$ & 0.098 & 1.784 & 95 \\
\hline $900^{\circ} \mathrm{C}$ & 0.361 & 1.308 & 72 \\
\hline $1000^{\circ} \mathrm{C}$ & 0.773 & 1.791 & 57 \\
\hline
\end{tabular}

As noted above, vanadium oxide $\left(\mathrm{V}_{2} \mathrm{O}_{5}\right)$ being part of the $\mathrm{SCR}$ catalyst has catalytic properties when converting $\mathrm{SO}_{2}$ to $\mathrm{SO}_{3}$. In modern catalysts, the conversion rate on $\mathrm{SCR}$ installations is roughly $1-2 \%$. A ccording to $L u$ et al. [6], conversion increases in the presence of ammonia in flue gas as well as in the presence of $\mathrm{V}_{2} \mathrm{O}_{5}, \mathrm{WO}_{3}$ and $\mathrm{TiO}_{2}$. These compounds constitutes a catalyst, that is most often applied in SCR reactors. Also, if the ratio $\mathrm{NH}_{3} / \mathrm{NO}$ is higher than 0.6 , the conversion raises. The effect of oxygen concentration, $\mathrm{NO}$ concentration as well as $\mathrm{Al}_{2} \mathrm{O}_{3}$ is relatively small on the other hand. A Iso the conversion rate drops when the amount of $\mathrm{SiO}_{2}$ and $\mathrm{BaO}$ increases [6]. Taking this into account, it is important to ensure that SCR installation operates at its optimal conditions. Operational parameters (such as N $0 x$ concentration, temperature and flue gas flow before installation) should be observed. The essence of the exhaust gas temperature before the SCR installation is particularly important - when it is too low, there is an increased slip of ammonia, when it is too high increased amount of sulfur trioxide can be formed [8].

In the zone of the rotary air heater, the sulfur trioxide $\mathrm{SO}_{3}$ reacts with the steam to form sulfuric acid (VI) according to the equation:

$\mathrm{SO}_{3}(\mathrm{~g})+\mathrm{H}_{2} \mathrm{O}->\mathrm{H}_{2} \mathrm{SO}_{4}(\mathrm{~g})$

This reaction takes place in temperature range between $204^{\circ} \mathrm{C}$ and $426^{\circ} \mathrm{C}$. At temperatures below $204^{\circ} \mathrm{C}$, sulfuric acid is also in the form of an aerosol [8]. Sulfuric (VI) acid is dangerous at temperatures below its condensation point, bringing risk of corrosion occurrence. The temperature of this point increases proportionally to the partial pressure of water vapor and $\mathrm{SO}_{3}$ in exhaust gases. A typical temperature range in which $\mathrm{H}_{2} \mathrm{SO}_{4}$ condensates is in the range of $95-160^{\circ} \mathrm{C}$. The increased $\mathrm{SO}_{3}$ content can therefore lead to sulfuric acid condensation at the cold end of the air heater. The relationship between the sulfuric acid condensation temperature and $\mathrm{SO}_{3}$ concentration in the flue gas after the rotating air preheater, is presented in the Table 2 [9] [10].

Table 2. The relationship between the sulfuric acid condensation temperature and $\mathrm{SO} 3$ concentration

\begin{tabular}{|l|l|}
\hline Acid dew point & $\mathrm{SO}_{3}$ concentration \\
\hline $155^{\circ} \mathrm{C}$ & $60 \mathrm{ppm}$ \\
\hline $146^{\circ} \mathrm{C}$ & $30 \mathrm{ppm}$ \\
\hline $124^{\circ} \mathrm{C}$ & $5 \mathrm{ppm}$ (desired value) \\
\hline
\end{tabular}

Although there is a high probability that the flue gas will cool below the acid dew point temperature, the first signs of corrosion caused by sulfuric acid condensation should be expected only at temperatures below $70-80^{\circ} \mathrm{C}$ [10]. A bove this temperature, condensing sulfuric acid will rather bind sticking ash particles together which, however, does not lead to the corrosion of particular surfaces. A nother problem for rotating air preheater is further discussed occurrence of liquid ammonium bisulfate [5].

\section{SO3 concentration in flue gas}

Considering the pulverized coal boiler, it can be estimated that the level of sulfur dioxide emissions is, for the nominal load operation, in the range from about $1200 \mathrm{mg} / \mathrm{N} \mathrm{m}^{3}(458$ $\mathrm{ppm}$ ) to about $2500 \mathrm{mg} / \mathrm{Nm}^{3}$ (955 ppm), depending on the sulfur content in the fuel (from $0.7 \%$ to $1.1 \%$ ). A ssuming the $\mathrm{SO}_{2}$ to $\mathrm{SO}_{3}$ conversion (before $\mathrm{SCR}$ ) equals to $2 \%$, the corresponding range of $\mathrm{SO}_{3}$ concentration in the furnace chamber is from about $9.2 \mathrm{ppm}$ to $19.1 \mathrm{ppm}$. Part of $\mathrm{SO}_{3}$ reacts with alkal ine elements in fly ash to form compounds that settle on the boiler heating surfaces (e.g. $\mathrm{K}_{2} \mathrm{SO}_{4}$, $\mathrm{Na}_{2} \mathrm{SO}_{4}$ ). The associated $\mathrm{SO}_{3}$ reduction will therefore be directly proportional to the alkali content in fly ash. Part of $\mathrm{SO}_{3} / \mathrm{H}_{2} \mathrm{SO}_{4}$ is also adsorbed on the fly ash particles. A fter the flue gas passes through successive layers of the SCR installation, the $\mathrm{SO}_{3}$ concentration increases accordingly: about $5 \mathrm{ppm}$ in the first catalyst layer, about $6 \mathrm{ppm}$ in the second catalyst layer and about $6.5 \mathrm{ppm}$ in the third catalyst layer [8]. The above values may increase when the SCR install lation is turned off and the exhaust gas is not bypassed (increase by approx. 30\%). The reason for this is the main component of SCR catalysts - vanadium oxide - which al so acts as a catalyst for the conversion of $\mathrm{SO}_{2}$ to $\mathrm{SO}_{3}$. B esides that, the increased flue gas temperature and reduced flue gas flow can also influence conversion [8].

Occurrence of ammonia bisulfate in the boiler is important from power plant operation point of view, because it can easily deposit on heating surfaces as well as on SCR catalysts. M oreover, it aggregates fly ash particles carried by flue gas. Plugged heating surfaces would affect heat transfer while plugged catalyst surface would have lower activity. Temperature of ABS condensation has been subjected to numerous studies. There is no consistency for 
the results though. A ccording to Shi et al. [11] temperature of $\mathrm{ABS}$ condensation is in the range of $190^{\circ} \mathrm{C}-240^{\circ} \mathrm{C}$, but other authors indicate, that risk of $A B S$ formation may occur at any temperature. Ammonia bisulfate can be removed when flue gas temperature is higher than $400^{\circ} \mathrm{C}$, but this can bring about issues related with catalyst sintering on the other hand. Temperature of $A B S$ condensation is also related to the pores structure of the catalyst. For smaller pores, temperature may increase due to the capillary forces [12] [13]. It can be concluded, that the lower the temperature of SCR operation is, the higher the risk of ammonia bisulfate condensation will be. It is also important to notice, that SCR catalysts producers indicate that proper temperature for the installation should be between $300^{\circ} \mathrm{C}$ and $400^{\circ} \mathrm{C}$.

\section{Modelling of coal-fired boiler operation}

M odelling of the coal-fired boiler was made using Ebsilon Professional, the software for thermodynamic simulation of power units [14]. By utilizing this tool, it is possible to design and simulate single devices as well as technological systems for power or heat production. In coal-fired boiler, temperature of flue gas is not measured in every single region of the boiler. B esides that, in the first pass of the boiler, temperatures are too high to install traditional measurement sensors, which leaves room for acoustic temperature measurement systems only. The latter are usually used in combination with SNCR technologies, in order to seek for desired temperature window in real time. However, if the boiler is not equipped with proper flue gas temperature measurements, the only way to find out desired value of temperature, is to simulate the boiler operation. Because, from the SCR operation point of view, it is crucial to understand the temperature distribution, an pulverized coal-fired units with nominal capacity of $430 \mathrm{t} / \mathrm{h}$ was simulated. The schematic view of the boiler is shown on Fig. 1 while the corresponding thermodynamic model layout is shown on Fig. 2. What can be notice from Fig. 1, is that simulated boiler has only one stage of steam superheating, and the SCR installation is installed downstream the water heater. What can also be noticed from Fig. 1, is that SCR reactor has two catalytic layers and the third one is left empty. That is often the case for new installations, where the third layer is added after the overall activity of the installation drops under the required limit.

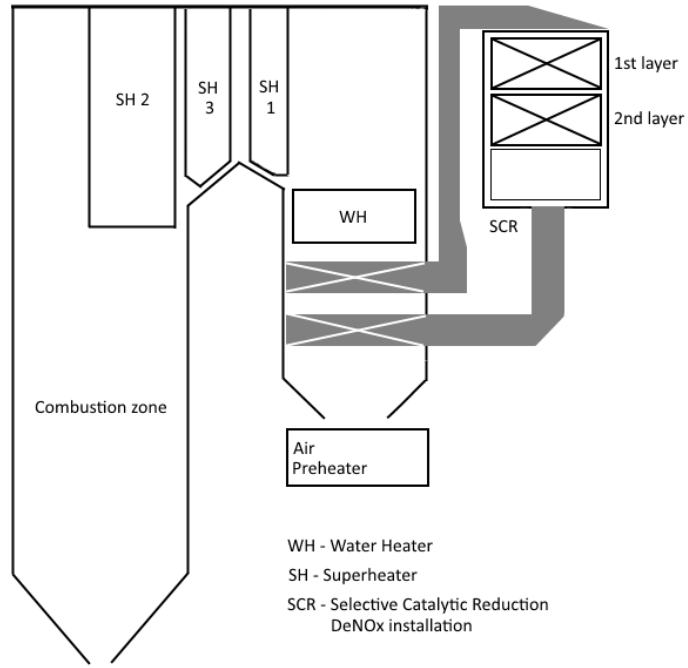

Fig. 1. Schematic view on the pulverized coal boiler with 430 t/h nominal capacity, equipped with DeN Ox SCR installation.

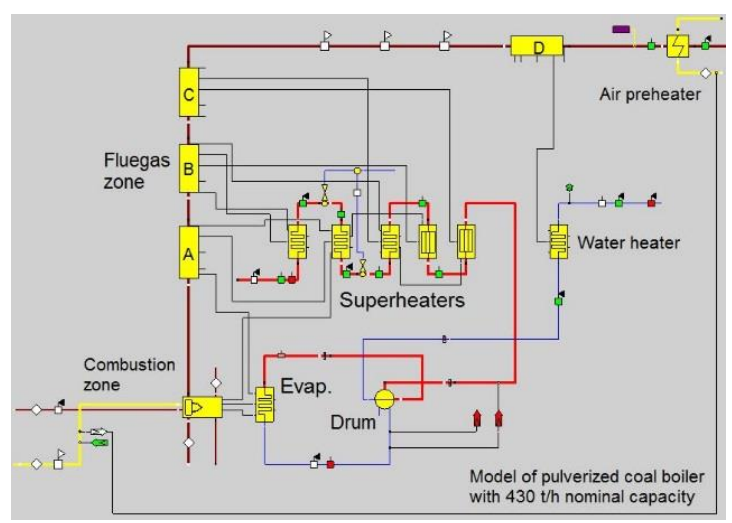

Fig. 2. Layout of the coal-fired boiler model in Ebsilon Professional software.

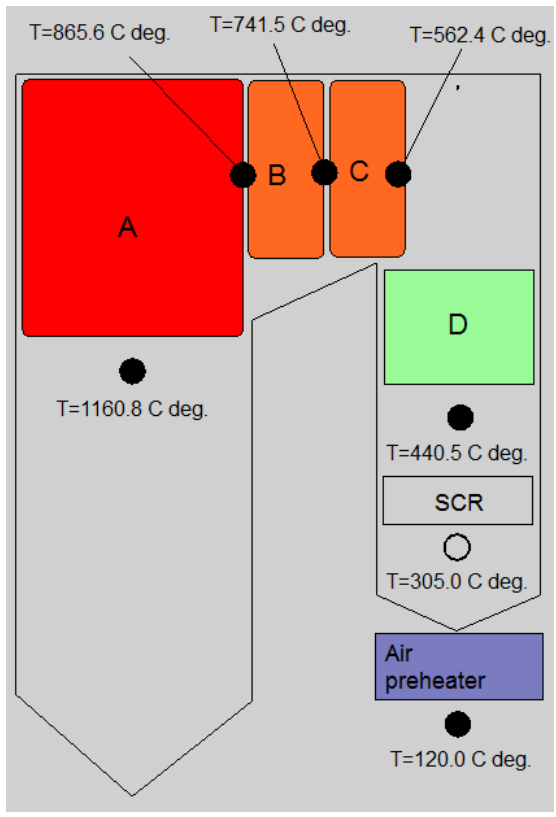

Fig. 3. Flue gas temperature distribution in $100 \%$ boiler load. 


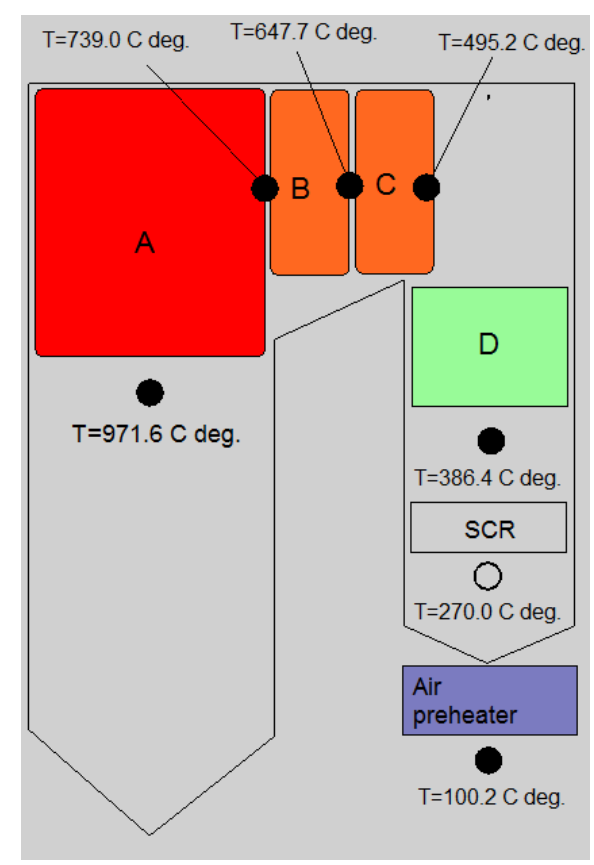

Fig. 4. Flue gas temperature distribution in $60 \%$ boiler load.

\section{Model outcomes and discussion}

Based on the model outcomes, flue gas temperature distribution along the boiler was determined for nominal $(100 \%)$ and minimal $(60 \%)$ load. Results are shown on Fig. 3 and Fig. 4. Rectangles marked with capital letter (A-D), represent areas of the boiler, from where heat is conveyed (through the radiation and convection mechanism) to superheaters and other heat exchangers installed in the boiler. Temperatures indicated by black dots, are calculated as an average value for the cross section between regions A-D. In order to simulate exact temperature in every single place of the boiler, more advance simulation techniques, like Computational Fluid Dynamics (CFD), must be applied. Because the region D represent heat absorbed the water heater, that means temperature calculated downstream this region is also the temperature at the inlet of SCR installation. The temperature downstream the SCR installation shown on Fig. 3 and Fig. 4 (transparent dot), is adopted from power plant measurement system, as the model does not include calculations for temperature drop at the SCR installation.

\section{Conclusion}

In this paper, mechanism of ammonia bisulfate formation was comprehensively described. Also, the mechanism of the $\mathrm{SO}_{2}$ to $\mathrm{SO}_{3}$ conversion in coal-fired boiler was discussed. In order to investigated temperature of SCR installation operation, the thermodynamic model of an 430 $\mathrm{t} / \mathrm{h}$ capacity coal-fired boiler was simulated in nominal and minimal load operation. The ammonia bisulfate is dangerous for boiler operation, because it contaminates active surface of the SCR catalyst as well as the cold end of rotating air preheaters. To avoid, or at least reduce issues related with ammonia bisulfate, it is crucial to maintain proper flue gas temperature as well as prevent excessive ammonia slip and $\mathrm{SO}_{3}$ formation.

\section{Acknowledgements}

M. Żyrkowski acknowledges the financial grant of the $M$ inistry of Science and Higher Education no. 0039/DW /2018/02

\section{References}

[1] G. Qi i R. T. Yang, „Performance and kinetics study for low-temperature SCR of $\mathrm{NO}$ with $\mathrm{NH} 3$ over

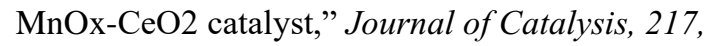
pp. 434-441, 2003.

[2] P. S. Hammershoi, P. N. V ennestrom, H. Falsig, A. D. Jansen i T. V. Janssens, ,Importance of the $\mathrm{Cu}$ oxidation state for the $\mathrm{SO} 2$ poisoning of a $\mathrm{Cu}$ SAPO-34 catalyst in the N H 3-SCR reaction," Applied Catalysis B: Environmental, 236, pp. 377383, 2018.

[3] L. Song, J. Chao, Y. Fang, H. He, J. Li, W. Qiu i G. Zhang, ,Promotion of ceria for decomposition of ammonia bisulfate over $\mathrm{V} 205-\mathrm{M} \mathrm{003/T} \mathrm{i02} \mathrm{catalyst}$ for selective catalytic reduction," Chamical Engineering Journal, 303, pp. 275-281, 2016.

[4] S. Y oun, I. Song, H. Lee, S. J. Cho i D. H. Kim, „Effect of pore structure of $\mathrm{TiO} 2$ on the $\mathrm{SO} 2$ poisoning over $\mathrm{V} 205 / \mathrm{TiO} 2$ catalysts for selective catalytic reduction of NOx with NH3," Catalysis Today, 303, pp. 19-24, 2018.

[5] R. Sporl, J. Maier i G. Scheffknecht, „Sulphur Oxide Emissions from Dust-Fired Oxy-Fuel Combustion of Coal," Energy Procedia, 37, pp. 1435-1447, 2013.

[6] J. Lu, Z. Zhou, H. Zhang i Z. Yang, ,Influenced factors study and evaluation for $\mathrm{SO} 2 / \mathrm{SO}_{3}$ conversion rate in SCR process," Fuel, 245, pp. 528-533, 2019.

[7] P. Marier i H. P. Dibbs, „The catalytic conversion of $\mathrm{SO} 2$ to $\mathrm{SO} 3$ by fly ash and capture of $\mathrm{SO} 2$ and $\mathrm{So} 3$ by $\mathrm{CaO}$ and $\mathrm{MgO}$," Thermochem. Acta., 8, pp. 155-165, 1974.

[8] Breen Energy Solutions, „Comprehensive acid gas management," 2012. [Online]. A vailable:

http://breenes.com/wpcontent/uploads/2017/04/Comprehensive_Condensa ble_M anagement_Program-RevA.pdf. [Data uzyskania dostępu: July 2019].

[9] W. Wei, F. Sun, Y. Shi i L. Ma, „Theoretical prediction of acid dew point and safe operating 
temperature of heat exchangers for coal-fired power plants," Applied Thermal Engineering, 123, pp. 782-790, 2017.

[10] Z. Li, F. Sun, Y. Shi, F. Li i L. Ma, „Experimental study and mechanism analysis on low temperature corrosion of coal fired boiler heating surface," Applied Thermal Engineering, 80, pp. 355-361, 2015.

[11] Y. Shi, H. Shu, Y. Zhang, H. Fan, Y. Zhang i L. Yang, ,Formation and decomposition of NH4HSO4 during selective catalytic reduction of $\mathrm{NO}$ with NH3 over V 205-WO3/TiO2 catalysts," Fuel Processing Technology, 150, pp. 141-147, 2016.

[12] C. Zheng, Y. W ang, Y . Liu, Z. Y ang, R. Q u, D. Y e, C. Liang, S. Liu i X. Gao, „Formation, transformation, measurement, and control of $\mathrm{SO}_{3}$ in coal-fired power plants," Fuel, 241, pp. 327-346, 2019.

[13] Charles A . L ockert, B reen Energy Solution., „Dynamic Control of SCR Minimum Operating Temperature,” w CoalGen, 2009.

[14] „EBSILON®Professional for the design of power plants," STEAG Energy Services, [Online]. A vailable: https://www.steagsystemtechnologies.com/en/products/ebsilonprofessional/. [Data uzyskania dostępu: 2019].

[15] L. M uzio, S. B ogseth, R. Himes, Y. Chien i D. Dunn-Rankin, ,Ammonium bisulfate formation and reduced load SCR operation," Fuel, 206, pp. 180189, 2017.

[16] J. M enasha, D. Dunn-Rankin, L. M uzio i ] . Stallings, „Ammonium bisulfate formation temperature in a bench-scale single-channel air preheater," Fuel, 90, pp. 2445-2453, 2011.

[17] S. Shwan, W. Partridge, J. Choi i L. Olsson, „Kinetic modeling of NOx storage and reduction using spatially resolved MS measurements," Applied Catalysis B: Environmental, 147, pp. 10281041, 2014.

[18] G. Dolanc, S. Strmcnik i J. Petrovcic, „NOx selective catalytic reduction control based on simple models," Journal of Process Control, 11, pp. 35-51, 2001. 